\title{
Trabzon yöresinde yetişen Sibirya kivisi (Actinidia arguta) meyvesinin fenolik bileşiklerinin karakterizasyonu ile antioksidan ve antimikrobiyal aktivitesinin belirlenmesi
}

\section{Determination of the phenolic compound profile, antioxidant capacity and antimicrobial activity of Siberian kiwifruit (Actinidia arguta) grown in Trabzon Region}

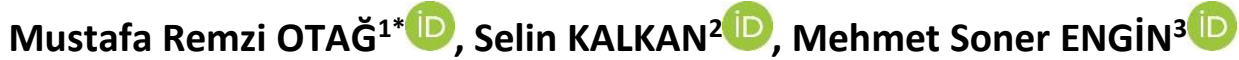 \\ ${ }^{1 *}$ Giresun Üniversitesi, Mühendislik Fakültesi, Gıda Mühendisliği Bölümü, Giresun, Türkiye \\ ${ }^{1}$ https://orcid.org/0000-0001-5450-1546; ${ }^{2}$ https://orcid.org/0000-0002-4142-3152; ${ }^{3}$ https://orcid.org/0000-0001-5954-5628
}

To cite this article:

Otağ, M.R., Kalkan, S. \& Engin, M.S (2021). Trabzon yöresinde yetişen Sibirya kivisi (Actinidia arguta) meyvesinin fenolik bileşiklerinin karakterizasyonu ile antioksidan ve antimikrobiyal aktivitesinin belirlenmesi. Harran Tarım ve Gıda Bilimleri Dergisi, 25(3): 362-376.

DOI: 10.29050/harranziraat.889594

*Address for Correspondence: Mustafa Remzi OTAĞ

e-mail:

mustafa.otag@giresun.edu.tr

Received Date

02.03.2021

Accepted Date:

10.06.2021
Öz

Bu çalışmada, literatürde hakkında sınırlı sayıda çalışma bulunan Sibirya kivisi meyvesinin farklı çözgenler (etanol ve metanol) kullanılarak elde edilen ekstraktlarında toplam fenolik madde içerikleri ve bu bileşiklerin dağılımı, antioksidan aktivite ve antimikrobiyal aktivitelerinin incelenmesi amaçlanmıştır. Bu amaçla, ilk aşamada bitkinin fenolik bileşikleri ekstrakte edilerek en etkin çözgen sistemi tespit edilmiştir. Çalışmanın ikinci aşamasında ise elde edilen ekstraktların çözgenleri uçurularak kalan kuru maddede kromatografik olarak fenolik bileşiklerinin dağılımı ile spektrofotometrik olarak antioksidan aktiviteleri ve son olarak önemli gıda patojenlerine karşı antimikrobiyal aktiviteleri belirlenmiştir. Meyvelerin etanol ve metanol ekstraktlarında toplam fenolik içeriği ve antioksidan aktivitesi Folin-Ciocalteu ve ABTS antioksidan aktivite metotlarına göre tespit edilmiştir. Kivi örneklerinin fenolik profili HPLC-UV ile belirlenmiştir. 2017 yılında hasat edilen etanol ve metanol ile ekstrakte edilen Sibirya kivi

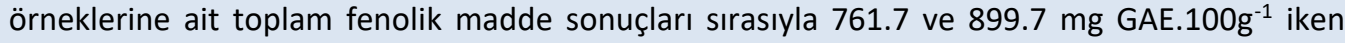
2018 yılında hasat edilen örneklerin etanol ve metanol ile ekstraktları ise 783.5 ve $931.6 \mathrm{mg}$ GAE. $100 \mathrm{~g}^{-1}$ olarak bulunmuştur. 2017 hasat edilen etanol ve metanol ile ekstrakte edilen Sibirya kivi örneklerine ait ABTS antioksidan aktivite değerleri ise sırasıyla 87.6, 94.2 $\mu \mathrm{M} \mathrm{TE} . \mathrm{g}^{-1}$ TA iken 2018 yılında hasat edilen örneklerin ise 111.4 ve $118.1 \mu \mathrm{M} \mathrm{TE} . \mathrm{g}^{-1}$ TA olarak tespit edilmiştir. Antimikrobiyal aktive sonuçları değerlendirildiğinde kivi meyvesinin metanol ekstraktları, etanol ekstraktlarına kıyasla daha yüksek bir antimikrobiyal etki göstermiştir. 2017 yılının hasatı olan kivi metanol ekstraklarının en yüksek antimikrobiyal etkiyi $40 \mu \mathrm{L}$ emdirilen disk ile, Vibrio parahemolyticus, Enterococcus faecalis, Salmonella Typhimurium ve Proteus vulgaris'e $(12.5 \pm 0.7 \mathrm{~mm})$ gösterdiği tespit edilmiştir. 2018 yılın hasatı olan kivi etanol ekstraktlarının ise Listeria monocytogenes'e $(13.5 \pm 0.7 \mathrm{~mm})$ karşı en yüksek antimikrobiyal aktiviteyi $40 \mu \mathrm{L}$ emdirilen disk ile gösterdiği belirlenmiştir.

Anahtar Kelimeler: Actinidia arguta, Antioksidan kapasite, Biyolojik aktivite, Fenolik içerik

\section{ABSTRACT}

The aim of this study is to investigate the total phenolic content and distribution of these compounds, antioxidant capacity and antimicrobial activities in the extracts of Siberian kiwifruit, which has not been studied much, using different solvents. At the first stage, the most effective solvent system of the kiwifruit to extract phenolic compounds was tried to be determined. In the second phase of the study, solvents were removed using a rotary evaporator to obtain extracts and the profiles of phenolic compounds in the remaining dry matter was tried to be determined by chromatographic, antioxidant activities by spectrophotometric method and finally antimicrobial activities were obtained by microbiologically. Phenolic profile of kiwi samples was determined by HPLC-UV. Total phenolic substance results of Siberian kiwi samples extracted with ethanol and methanol harvested in
(C) Copyright 2018 by Harran University Faculty of Agriculture. Available on-line www.dergipark.gov.tr/harranziraat

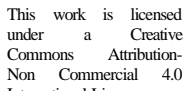


2017 and 2018 were found to be 761.7, 899.7, 783.5 and 931.6 mg GAE. 100 ${ }^{-1}$, respectively. ABTS antioxidant activity values of Siberian kiwi samples extracted with ethanol and methanol harvested in 2017 and 2018 were determined as 87.6, 94.2, 111.4 and $118.1 \mu \mathrm{M}$ TE g ${ }^{-1}$ TA, respectively. When the antimicrobial activity results were evaluated, the methanol extracts of kiwifruit showed a higher antimicrobial effect compared to ethanol extracts. It has been determined that kiwi methanol extracts $(40 \mu \mathrm{L})$ harvested in 2017 showed the highest antimicrobial effect to Vibrio parahemolyticus, Enterococcus faecalis, Salmonella Typhimurium and Proteus vulgaris (12.5 $\pm 0.7 \mathrm{~mm}$ ). And, it was determined that kiwi ethanol extracts (40 $\mu \mathrm{L}$ ), harvested in 2018, showed the highest antimicrobial activity against Listeria monocytogenes (13.5 $\pm 0.7 \mathrm{~mm}$ ).

Key Words: Actinidia arguta, Antioxidant capacity, Biological activity, Phenolic content

\section{Giriş}

Kivi, anavatanı olarak kabul edildiği doğu ve güney Çin'de doğal ortamda kendiliğinden yetişen bir meyvedir. İtalya başta olmak üzere Yeni Zelanda, ABD, Fransa, Şili ve Japonya gibi ülkelerde de üretilmektedir. Türkiye'de ise kivi üretim çalışmaları 1988 yılında başlamıştır (Krupa ve ark., 2011). Illk olarak Yalova Atatürk Bahçe Kültürleri Merkez Araştırma Enstitüsü tarafından sahil bölgeleri ağırlıklı olmak üzere farklı ekolojilerde adaptasyon bahçeleri kurulmuştur. Yapılan bu çalışmalar sonucu Karadeniz bölgesi başta olmak üzere Marmara ve Ege sahil bölgelerinin kivi yetiştiriciliğine uygun olduğu tespit edilmiştir (Samancı,1990). Doğu Karadeniz Bölgesi'nde tarımla uğraşan insanların tamamına yakınının ana geçim kaynağı çay ve fındıktır. Yöre halkının bu bitkilerden istenilen geliri elde edememesi ve kivi yetiştiriciliğinin bu bölgede coğrafi ve iklim açısından elverişli olması yöre halkını ek gelir getirmek amacıyla kivi yetiştiriciliğine yöneltmiştir. Yörenin ikinci tarım ürünü haline gelmeye başlayan ve her yıl yöre ekonomisine katkısını artırarak sürdüren kivi, üreticiye ek gelir imkânı sağlamaktadır. Doğu Karadeniz Bölgesi'nde uygun sıcaklığın olması, yağışların düzenli olması, kış soğuklarının kivi yetiştiriciliğini olumsuz yönde etkilememesi gibi faktörler kivinin bölgeye adaptasyonunu sağlamıştır (Türkkan ve ark., 2018). Ülkemizde 20 yılı aşkın süredir yapılan kivi üretimi giderek artış göstermektedir. Türkiye'de kivi üretimi yapılan alanların \%70'i Karadeniz Bölgesi'nde bulunmaktadır (Yonat ve Kolören, 2017). Marmara Bölgesi kivi üretimi yapılan alanların \%27'sine, Akdeniz ve Ege Bölgesi ise \%3'üne sahiptirler. Türkiye'deki kivi üretimi en çok başta Yalova olmak üzere ardından Ordu, Rize, Samsun,
Giresun, Trabzon ve diğer 18 ilde yapılmaktadır. Lezzeti, besin değeri, verimi ve muhafaza süresinin uzunluğu gibi nedenlerle, yeşil meyve etli Hayward çeşidi en çok tercih edilen çeşittir. Bu yüzden dünya ve ülkemizdeki kivi üretiminin büyük bir kısmını Hayward çeşidi oluşturmaktadır (Çelik ve ark.,2009)

Sibirya kivisi, coğrafi ve iklim koşullarına çeşide ve yetiştirme yöntemine bağlı olarak değişmekle birlikte zengin bir kimyasal bileşime sahiptir. Meyveler, insan sağlığı için önemli olan, fizyolojik ve biyokimyasal faydaları belirlenmiş önemli düzeyde biyoaktif maddeler içermektedirler. Egzotik meyveler, özellikle kivi, avokado, mango ve Trabzon hurması, bileşimleri nedeniyle yüksek besin ve biyoaktif özelliklere sahiptir (Park ve ark., 2006; Gorinstein ve ark., 2010; Gorinstein ve ark., 2011). Actinidia (A.) kivi meyvesinin en popüler türleri Actinidia deliciosa, Actinidia chinensis ve Actinidia eriantha'dır, ancak Actinidia arguta, Actinidia kolomikta ve Actinidia purpurea gibi diğer türler, donma direnci nedeniyle daha soğuk iklimin hakim olduğu bölgelerde de büyüyebilirler (Chesoniene ve ark., 2004). Sert kivi olarak da bilinen Actinidia arguta, zaman içerisinde piyasada bebek kivisi adı altında satılarak popüler hale gelmiştir (Kabaluk ve ark.,1997; Williams ve ark., 2003). Bu meyvenin yenilebilir pürüzsüz bir yüzeyi vardır. Yüksek miktarda şeker ve askorbik asit içeren bu kivi çeşidi mükemmel bir lezzete sahiptir. Sibirya kivisi (A. arguta), Doğu Asya'nın büyük bir bölümüne yayılmıştır ve Japonya'daki dağlık bölgelerde yaygın olarak görülmektedir (Ohashi, 1989). Birçok çeşide sahip olmasına rağmen hemen hemen bütün çeşitlerde meyve, 6$16 \mathrm{~g}$ ağırlığında ve ticari kivi (A. deliciosa) meyvesinden daha küçük bir yapıya sahiptir(Williams ve ark., 2003). Meyveleri olgun 
çilek, muz, ananas, aşırı olgun armut, ravent, frenk üzümü, kavun ve tropikal tatlarla karşılaştırıldığında tatlı ve yoğun bir lezzete sahiptir ayrıca son derece aromatiktir (Matich ve ark., 2003; Williams ve ark., 2003). Sibirya kivisi, $100 \mathrm{~g}$ meyve başına 25 ile $155 \mathrm{mg}$ C vitamini içerir (Kabaluk ve ark., 1997) ve nutrasötiklerce de nispeten zengindir.

Tüketicilerin sağlıklı beslenme konusunda bilinçlenmeleri sebebiyle antioksidan aktiviteye sahip olan gıdalara olan ilgileri artış göstermektedir. Meyveler, özellikle içerdikleri fenolik bileşiklerin antioksidatif ve antimikrobiyal etkilerine bağlı olarak sağlık üzerinde olumlu etki yaratmaktadırlar. Özellikle bitki ekstraktları ile antibiyotiklerin sinerjistik etkilerinin bilinmesi, doğal, ucuz ve daha az yan etkiye sahip alternatif bir yaklaşım olarak ortaya çıkmaktadır. Böylelikle daha düşük dozda antibiyotik kullanılarak daha etkili sonuçlar elde etmek mümkün olabilmektedir (Akmeşe ve ark., 2020). Bilindiği gibi, kivi meyvesi biyoaktif maddelerinden etkilenen antioksidan özelliklere sahiptir. Bir yandan toplam fenolik madde içeriği ile diğer yandan $C$ vitamini içeriği ile antioksidan aktivite ile polifenoller arasında yüksek korelasyon bulunmuştur (Du ve ark., 2009; Park ve ark., 2011). Ülkemiz için yeni sayılabilecek bir meyve olması ve yetiştiriciliği için çalışmaların da hali hazırda devam ediyor olması bu meyveye olan ilgiyi daha da arttıracağı düşünülmektedir. Bu çalışmada, üzerinde çok fazla çalışma yapılmamış Sibirya kivisi meyvesinin farklı çözgenler (etanol ve metanol) kullanılarak elde edilen ekstraktlarında toplam fenolik madde içerikleri ve bu bileşiklerin dağılımı, antioksidan ve antimikrobiyal aktivitelerini incelemek amaçlanmıştır. Çalışmanın ilk aşamasında bitkinin fenolik bileşiklerini ekstrakte edecek en etkin çözgen sistemi tespit edilmiştir. Çalışmanın ikinci aşamasında ise elde edilen ekstraktların çözgenleri uçurularak kalan kuru maddede kromatografik olarak fenolik bileşiklerinin dağılımı ile spektrofotometrik olarak antioksidan aktiviteleri belirlenmiştir. Ayrıca farklı çözgenlerle elde edilen ektraktların önemli gıda kaynaklı patojen mikroorganizmalar antimikrobiyal aktiviteleri tespit edilmiştir.

\section{Materyal ve Metot}

\section{Materyal}

Analizlerde kullanılmak üzere 2017 yılı için Ekim ayının son haftası ve 2018 yılı hasat döneminde Kasım ayının ikinci haftasında Trabzon'un Dernekpazarı ilçesindeki kivi bahçesinden daha önceden belirlenen 12 ağacın 3 farklı kısmından \% 7-9 briks değerine ulaşmış tek düze görünür kusuru bulunmayan taze şekilde toplanan Sibirya kivileri (Actinia arguta) plastik poşetlere konularak soğuk saklama koşullarında Giresun Üniversitesi Gıda Mühendisliği Bölümü Laboratuvarına getirilmiştir. Örneklerin kabukları soyulduktan sonra yenen kısmı için etanol ve metanol çözgenleri kullanılarak ekstraksiyon yöntemiyle analiz numuneleri elde edilmiştir.

Çalışmada kullanılan Gram pozitif ve Gram negatif test mikroorganizmalarl; Listeria monocytogenes, Staphylococcus aureus (ATCC 25923), Escherichia coli Type 1, Vibrio parahaemolyticus (ATCC 17802), Bacillus cereus, Salmonella Typhimurium (ATCC 14028), Staphylococcus epidermis (ATCC 12228), Yersinia pseudotuberculosis (ATCC 911), Enterococcus faecalis (ATCC 29212), Klebsiella pneumoniae (ATCC 700603) ve Proteus vulgaris (ATCC 13315) bakterileri Giresun Üniversitesi Gıda Mühendisliği Bölümü kültür koleksiyonundan temin edilmiştir.

Sibirya Kivisi (Actinidia arguta) meyvesinin ekstraksiyonu

Sibirya kivisi meyvelerinin ekstraksiyonu için Mulero ve ark. (2010) metodu modifiye edilerek kullanılmıştır. Buna göre $50 \mathrm{~g}$ taze ve olgunlaşmış kabuğu soyulmuş meyve tartılıp yüksek devirli blenderda (Waring-USA) parçalanarak homojen hale getirildikten sonra $50 \mathrm{~mL}(\% 80 \mathrm{v} / \mathrm{v}$ ) etanol ve metanol ile karanlıkta $25^{\circ} \mathrm{C}$ sıcaklığa ayarlanmış çalkalamalı su banyosunda 2 saat süreyle bekletilmiştir. Süre sonunda 15 dakika ultrasonik su banyosunda bekletilen örnekler önce 2000 rpm'de 10 dakika santrifüj edilmiştir. Daha sonra ise, ilk santrifüjden elde edilen berrak kısımlar 
(supernatantlar) $6000 \mathrm{rpm}$ (devir/dakika)'de 20 dakika süreyle ikinci bir santrifüjleme işlemine tabi tutulmuştur. Ekstraksiyon işleminden sonra elde edilen kivi ekstraktları toplam fenolik madde, antioksidan, antimikrobiyal aktivite ve fenolik maddelerin HPLC ile belirlenmesinde kullanılmak üzere ayrı ayrı örnek tüplerine konularak $-40^{\circ} \mathrm{C}$ sıcaklıkta derin dondurucuda muhafaza edilmiştir. Ekstraksiyon işlemi bittikten sonra çözgenlerin fazlası döner buharlaştırıcıda uçurularak uzaklaştırılmıştır.

\section{Fenolik bileşiklerin HPLC ile belirlenmesi}

Ekstraksiyon aşamasında elde edilen kivi ekstraktları $0.45 \mu \mathrm{m}^{\prime}$ lik membran filtreden geçirilerek filtre edilmiştir. Filtre edilen ekstraktın $100 \mu L^{\prime}$ si HPLC'ye enjekte edilmiştir. Fenolik bileşiklerin HPLC ile belirlenmesinde Velioğlu ve ark (2006) metodu modifiye edilerek kullanılmıştır. Örnekteki fenolik bileşiklerin tanımlanması, bileşiklerin kolondaki alıkonma süresi ve UV spektrumlarının ilgili standart maddelere ait süre ve spektrumlarla karşılaştırılmasıyla yapılmıştır. Fenolik bileşiklere ait piklerin tanımlanması ve konsantrasyonlarının hesaplanması bileşiklerin maksimum absorbans değeri verdiği dalga boyunda gerçekleştirilmiştir.

Bileşiklerin miktarlarının tespit edilmesinde bileşiklere ait HPLC kromatogramlarından elde edilmiş entegre alanlar ve standart maddelerin ara stok çözeltileri ile hazırlanmış kalibrasyon eğrilerinden yararlanılmıştır. Gallik asit, (+)kateşin, için $280 \mathrm{~nm}$; kafeik asit, p-kumarik asit için $320 \mathrm{~nm}$; kuersetin ve mirisetin için $360 \mathrm{~nm}$, fenolik bileşiklerin analizinde kullanılan dalga boylarıdır.

Fenolik ekstraktlar, Autosampler (ACC-3000T), pompa (LPG-3400SD), DAD detektörü (DAD3000); (Thermo Scientific ${ }^{\mathrm{TM}} \quad$ Dionex $^{\mathrm{TM}}$ Chromeleon $^{\mathrm{TM}}$ Chromatography Data System Software 7.1) ve ters fazlı C18 kolon (250x4.6 $\mathrm{mm}$ ) bulunduran Thermo Scientific ${ }^{\mathrm{T}}{ }^{\mathrm{D}}$ Dionex $\mathrm{Tm}$ UltiMate ${ }^{\mathrm{TM}} 3000$ RSLC sistemi ile donatılmış HPLC sisteminde analiz edilmiştir. Fırın ve örnekleyici sıcaklığı 40 ve $25^{\circ} \mathrm{C}^{\prime}$ ye ayarlanmıştır. Mobil faz $\% 3$ (v/v)'lük asetik asit çözeltisi (Mobil faz A) ve

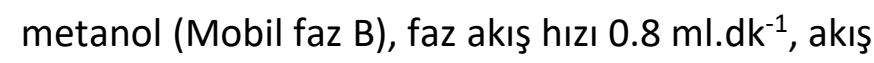
tipi gradient elüsyonu ve enjeksiyon hacmi ise 20 $\mu \mathrm{L}$ olarak belirlendi.

\section{Toplam fenolik madde tayini}

Folin-Ciocalteu Ayıracı ile toplam fenolik madde tayini metodun ilkesi; fenolik birleşiklerin bazik ortamda Folin-Ciocalteu ayıracının indirgenip kendilerinin oksitlenmiş forma dönüştüğü bir redoks reaksiyona dayanmaktadır. Ayraç burada oksitleyici bileşik olarak rol almaktadır. Reaksiyon sonucunda indirgenmiş ayracın oluşturduğu mavi rengin fotometrik olarak ölçülmesiyle, analizi yapılan örneklerdeki fenolik bileşiklerin toplam miktarlarının hesaplanması mümkün olacaktır. Standart çözelti olarak gallik asit çözeltisi kullanılmıştır (Slinkard and Singleton, 1977). Örneklerden etanol ve metanol ekstraksiyonu ile elde edilen ekstraktları analiz edilene kadar buzdolabında ve karanlıkta muhafaza edilmiştir. Analiz için $500 \mu \mathrm{L}$ ekstrakt üzerine $2.5 \mathrm{~mL}$ Folin-Ciocalteu reaktifi ilave edilerek oda sıcaklığında 3 dakika bekletilmiştir. Daha sonra karışım üzerine \% 7.5'lik $2 \mathrm{~mL}$ sodyum karbonat $\left(\mathrm{Na}_{2} \mathrm{CO}_{3}\right)$ çözeltisi ilave edilerek vorteks yardımıyla karıştırılmıştır. Elde edilen karışım oda şartlarında 1 saat süreyle karanlık ortamda inkübasyona bırakıldıktan sonra spektrofotometrede (Hach DR6000, Lange GmbH, 189 Germany) $720 \mathrm{~nm}$ dalga boyunda kontrole karşı absorbansları okunmuştur. Sonuçların eldesinde okunan absorbans değerleri standart gallik asit kurvesi (0-500 mg. $\mathrm{L}^{-1}$ ) yardımıyla gallik asit cinsinden (mg GAE.100g ${ }^{-1}$ kuru ağırlık) toplam fenolik maddeye çevrilmiş ve daha sonra seyreltme faktörü ile çarpılmıştır.

\section{Antioksidan kapasite tayini}

Sibirya kivisi meyvesinin antioksidan kapasitelerini belirlemek için ABTS (2,2'-azinobis(3-etilbenzotiazolin-6-sulfonik asit)) kullanılmış ve 2017 ile 2018 yıllarında hasat edilen kivi örneklerinin etanol ve metanol ekstraktlarının birbirlerine göre performansları karşılaştırılmıştır.

ABTS yönteminin ilkesi, ABTS ve potasyum persulfat arasında gerçekleştirilen reaksiyon 
sonucu oluşan mavi/yeşil renkli $\mathrm{ABTS}^{+}$radikal katyonu tarafından tutulan antioksidatif maddelerin miktarının sentetik bir antioksidan olan Troloks'un standart miktarıyla kıyaslanarak bağıl ölçümünün sağlanmasına dayanmaktadır (Re ve ark., 1999). Analiz için gerekli çözeltilerden biri olan $\mathrm{ABTS}^{+}$çözeltisi analizden 1 gün önce hazırlanmış olup 12-16 saat karanlıkta bekletilmiştir. $\quad 7 \mathrm{mM}$ konsantrasyonunda hazırlanan $\mathrm{ABTS}^{+}$çözeltisi için $38.4 \mathrm{mg}$ ABTS ve 6.6 $\mathrm{mg}$ potasyum persülfat tartılmış olup $10 \mathrm{~mL}$ balon jojede hacme tamamlanmıştır. PBS (tuzlu fosfat tampon) çözeltisi için de $8 \mathrm{~g} \mathrm{NaCl} ; 0.2 \mathrm{~g} \mathrm{KCl} ; 1.44 \mathrm{~g}$ $\mathrm{Na}_{2} \mathrm{HPO}_{4} ; 0.24 \mathrm{~g} \mathrm{KH}_{2} \mathrm{PO}_{4}$ tartılarak yaklaşık $800 \mathrm{~mL}$ distile suda çözündürülüp $\mathrm{pH}$ değeri $\mathrm{HCl}$ ya da $\mathrm{NaOH}$ kullanılarak 7.4'e ayarlandıktan sonra distile su ile 1 L'ye tamamlanmıştır. ABTS çözeltisi $734 \mathrm{~nm}$ dalga boyunda $0.700 \pm 0.10$ absorbans verecek şekilde PBS çözeltisi ile seyreltilmiştir.

\section{Mikroorganizma kültürlerinin hazırlanması}

Selektif besiyerlerinde geliştirilen kolonilerden öze yardımı ile alınan her bir bakteri kolonisi, 5 mL'lik Nutrient Broth (Merck) besiyerine aşılanarak inkübasyona bırakılmıştır. İnkübasyon koşulları $37^{\circ} \mathrm{C}$ 'de 18 -24 saat olarak belirlenmiştir. Daha sonra elde edilen kültürlerden 0.5

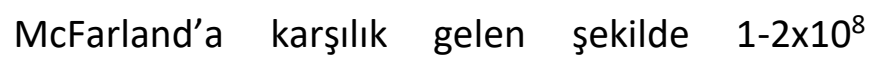
$\mathrm{KOB} / \mathrm{mL}$ hücre içeren bakteri stok solüsyonları hazırlanmıştır (Kalkan, 2016).

\section{Antimikrobiyal aktivitelerin belirlenmesi}

Kivi meyvesi ekstraktlarının antimikrobiyal aktiviteleri suşlara karşı disk difüzyon yöntemi kullanılarak Clinical Laboratory Standards Institute (CLSI, 2012) standartlarına göre yapılmıştır. Bakteri stok solüsyonlarından Mueller Hinton Agar (Merck) besiyerine $100 \mu \mathrm{L}$ aşılama yapılmış ve steril cam baget ile besiyeri yüzeyine yayıldıktan sonra 15-20 dk kurumaya bırakılmıştır. Disk difüzyon testi için; elde edilmiş kuru ve/veya balmumsu bitki ekstraktları dimetil sülfoksitte (\%99.9; DMSO) çözüldükten sonra stok kültürlerden aşılama yapılmış besiyerleri üzerine steril koşullarda yerleştirilmiş $6 \mathrm{~mm}$ çapındaki steril boş antibiyotik disklerine (Schleicher \&
Schül, Nr. 2668, Almanya) her bir diske 20, 30 ve $40 \mu \mathrm{L}$ olacak şekilde aseptik şartlara uyularak emdirilmiştir. Bu şekilde hazırlanmış besiyerleri bakteri kültürleri için $18-24$ saat $37^{\circ} \mathrm{C}^{\prime} \mathrm{de}$ inkübasyona bırakılmıştır. İnkübasyon sonrasında oluşan inhibisyon zonları cetvel yardımı ile ölçülerek kaydedilmiştir. Karşılaştırma yapmak amacıyla kontrol olarak boş steril diskler kullanılmıştır (Engin ve ark., 2019).

\section{istatistiksel analiz}

Verilerin analizleri SPSS (Version 16 for Windows, SPSS Inc.) programı ile yapılmış ve ortalamaıstandart sapma olarak kaydedilmiştir. Varyans analizleri ise ANOVA prosedürüne göre değerlendirilmiştir. Değerler arasındaki farklar ise Duncan çoklu karşılaştırma testine göre yapılmıştır. $p \leq 0.05$ değerleri önemli, $p \leq 0.01$ değerleri ise çok önemli olarak değerlendirilmiştir.

\section{Araştırma Bulguları ve Tartışma}

\section{Toplam fenolik madde içerikleri}

2017 ve 2018 yıllarında toplanan ve etanol ve metanol gibi iki farklı çözgen ile ekstrakte edilen Sibirya kivisi örneklerine ait toplam fenolik madde sonuçları Şekil 1'de verilmiştir. Şekil 1'de de görüldüğü gibi toplam fenolik madde miktarlarının kivi örneklerinde $761.7 \mathrm{mg}$ GAE.100g ${ }^{-1}$ ile $931.6 \mathrm{mg}$ GAE.100g ${ }^{-1}$ arasında değiştiği tespit edilmiştir. Analizi yapılan örnekler arasında en yüksek değerin 2018 yılında hasat edilen ve metanol ile ekstrakte edilmiş kivi örneklerinde (931.6 mg GAE.100g-1) olduğu tespit edilmiştir. Buna karşılık en düşük toplam fenolik madde değerinin 2017 hasat yılında toplanan ve etanol ile ekstrakte edilen Sibirya kivisi örneklerinde olduğu saptanmıştır. Genel olarak 2018 yılında toplanan kivi örneklerinin 2017 yılında toplanan kivi örneklerine göre daha yüksek toplam fenolik değere sahip olduğu görülmektedir. Bu durumun yıllar arasında beliren iklim koşullarından meydana geldiği düşünülmektedir. Ayrıca aynı yıllarda yapılan etanol ve metanol çözgenlerine bağlı olarak yapılan karşılaştırmada metanol ile ekstrakte 
edilen kivi örneklerinin etanol ile ekstrakte edilen kivi örneklerinden daha yüksek toplam fenolik madde değerinin saptandığı görülmektedir. Bu durumun metanolün etanole göre daha fazla miktarda fenolik bileşiği meyve bünyesinden almış olduğunu göstermektedir. Çalışmamıza benzer olarak Gümüşay ve Yalçın (2019) yürütülen çalışmada, taze kivi meyvelerinin toplam fenolik madde miktarı $262.7 \pm 19.9 \mathrm{mg} \mathrm{GAE} .100 \mathrm{~g}^{-1}$ olarak tespit edilmiştir. Çalışmamızda elde edilen değerler, bu değerlerin oldukça üstündedir.

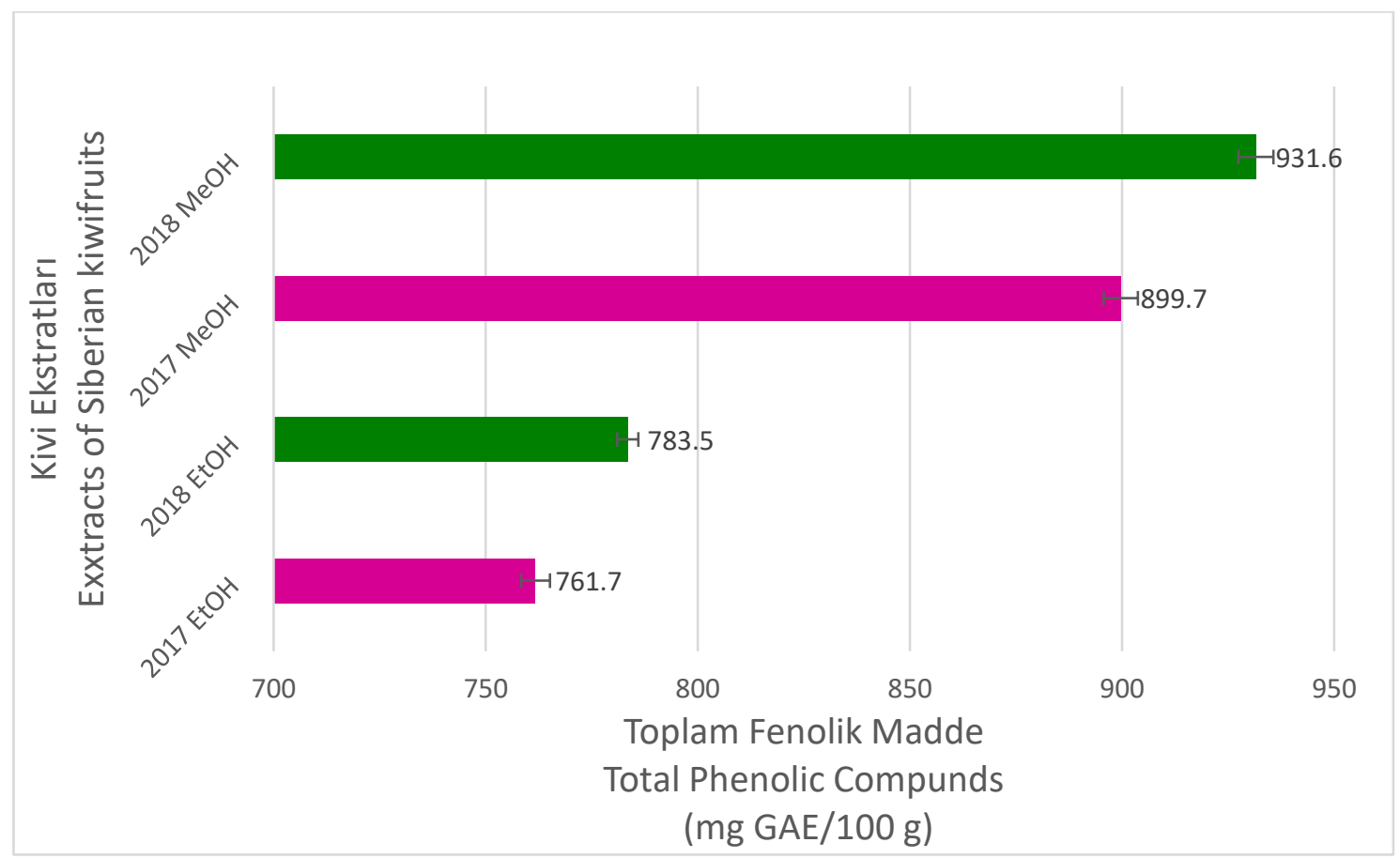

Şekil 1. Sibirya kivisi örneklerinin toplam fenolik madde miktarları

Figure 1. Total phenolic content of Siberian kiwifruit samples

Fenolik bileşik içerik analiz sonuçları (HPLC)

Sibirya kivisi örnekleri etanol ve metanol ile ekstrakte edildikten sonra geri kalan kalıntı kendi çözücülerinde de çözüldükten sonra HPLC-UV'de yürütülmüştür. Mobil faz olarak asetonitril, su ve fosforik asit kullanılarak kolonu terk etme zamanları olan elüsyon değerleri 15 adet standart fenolik bileşiğin elüsyon değeri ile karşılaştırılmıştır. Standartlara ait kromatogram Şekil 2'de verilmiştir.

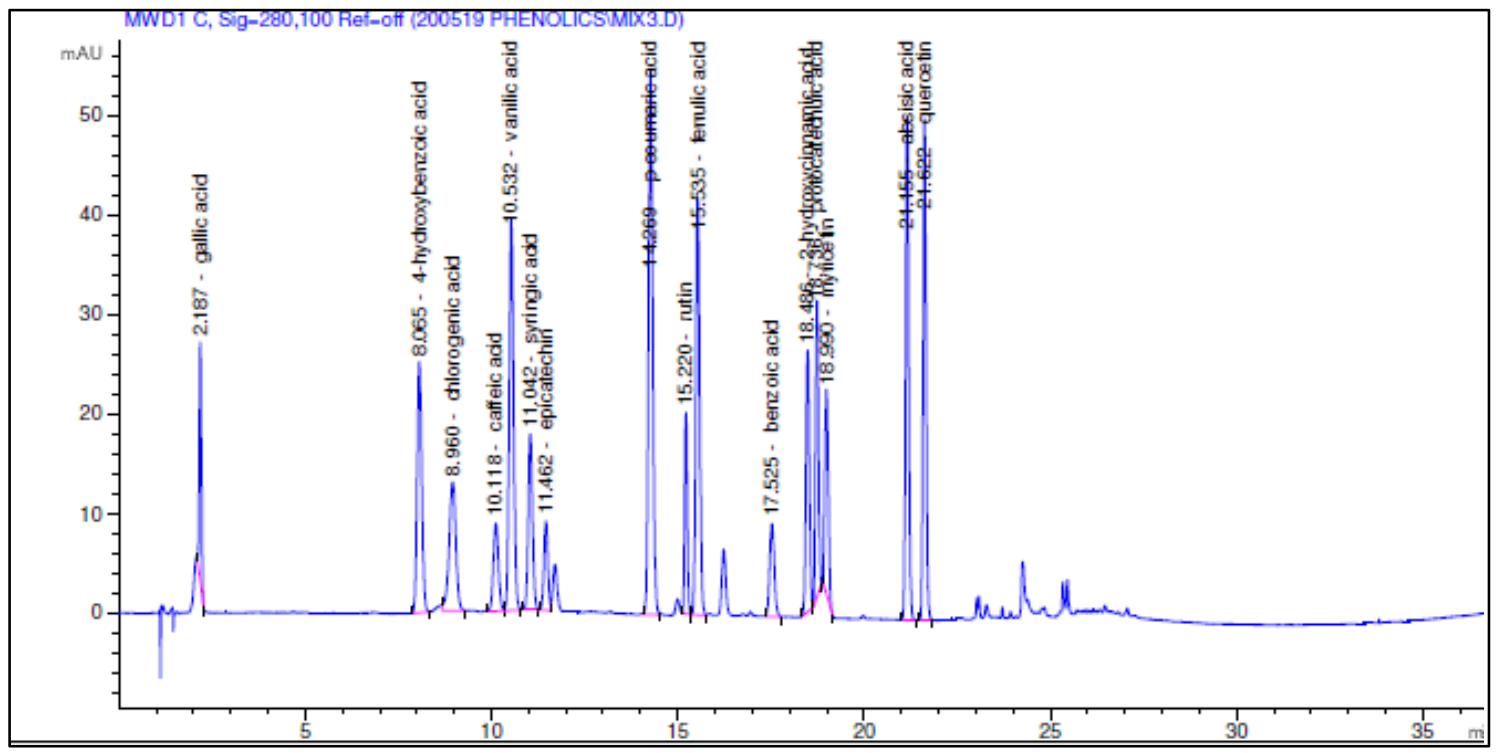

Şekil 2. Standart Fenolik bileşiklerine ait kromatogram

Figure 2. Chromatogram of standard phenolic compounds 
Kivi üzerine yapılan geçmiş çalışmalar incelendiğinde bu araştırmanın Sibirya kivi (Actinia arguta) çeşidinin farklı çözgen ekstraktlarındaki fenolik bileşiklerin karakterizasyonunu ve miktarını bildiren ilk çalışma olduğu görülecektir. 2017 ve 2018 yılllarında hasat edilen, etanol ve metanol gibi iki farklı çözgen ile ekstrakte edilen Sibirya kivisi örnekleri, 6 hidroksibenzoik asit (4hidroksibenzoik asit, gallik asit, vanilik asit, protokatekuik asit, benzoik asit ve siringik asit), 1 flavanol (kateşin), 3 flavonol (rutin, mirisetin ve kuersetin)ve 4 hidroksisinnamik asit (2hidroksisinamik asit, ferulik asit, kafeik asit, pkumarik asit) olmak üzere toplam 14 monomerik fenolik bileşik ve kivi meyvesinin olgunlaşmasında önemli rol üstlenen absisik asit ile çalışılmıştır. HPLC parametreleri optimize edilerek ve hem standart karışımın hem de örneklerin iyi pik çözünürlükleri elde edilmiştir Kivi örneklerinin bireysel fenolik seviyeleri Çizelge 1 'de verilmiştir.

Çizelge 1'de çalışılan Sibirya kivisi örneklerine ait HPLC-UV'de okunan fenolik bileşenler gösterilmektedir. Kivi örnekleri 2017-2018 yılları ve etanol ve metanol çözgen ekstraktları olmak üzere dört kısım analiz edilmiştir. 14 fenolik bileşen ve absisik aside göre yapılan analizlerin sonuçları Çizelge 1'de gösterilmiştir. Her iki yılda hasat edilen kivi örneklerinin fenolik bileşenlerin miktarı ve cinsi arasında farklılıklar görülmektedir.
Örneğin; benzoik asit 2018 yılında hasat edilen örneklerde tespit edilmezken, 2017 yılında hasat edilen ve her iki çözgen ile ekstrakte edilen kivi örneklerinde oldukça yüksek oranda belirlenmiştir. Bununla birlikte gallik asit 2017 yılında hasat edilen ve metanol ile ekstrakte edilen kivi örneklerinde belirlenmişken diğer örneklerde tespit edilememiştir. Protokatekuik asit, mirisetin ve 2-hidroksisinamik asit hiç bir örnekte tespit edilmemiştir. 2017 hasat yılında etanol ile ekstrakte edilen kivi örneklerindeki en yüksek fenolik bileşikler p-kumarik asit ve kuersetin olurken tespit edilebilen en düşük fenolik bileşikler şiringik asit ve kafeik asit olmuştur. Aynı şekilde 2017 yılında metanol ile ekstrakte edilen kivi örnekleri için en yüksek fenolik bileşikler p-kumarik asit ve kuersetin olurken, tespit edilen en düşük fenolik bileşikler vanilik ve gallik asit olmuştur. Absisik asit 2017 yılında hasat edilen ve her iki çözgen ekstraktında tespit edilirken 2018 yılı ekstraktlarında bulunamamıştır. Genel olarak her iki yılda toplanan kivi örneklerinin etanol ve metanol ekstraktları karşılaştırıldığında metanol ekstraktlarının fenolik bileşikleri daha yüksek bulunmuşken yıllara göre karşılaştırma yapıldığında benzer bir trend belirlenememiştir. 2017 ve 2018 yıllarında toplanan ve etanol ve metanol ekstraktlarının HPLC kromatogramları Şekil 3'te gösterilmiştir.

Çizelge 1. HPLC-UV'de ölçülen kivi örneklerinin fenolik kompozisyonları (mg.L-1)

Table 1. Phenolic compositions of Siberian kiwi samples measured in HPLC-UV (mg. $\left.\mathrm{L}^{-1}\right)$

Örnekler /Samples

\begin{tabular}{|c|c|c|c|c|}
\hline \multirow{3}{*}{$\begin{array}{l}\text { Fenolik bileşen } \\
\text { Phenolic compunds }\end{array}$} & \multicolumn{2}{|c|}{ 2017-KE* } & \multicolumn{2}{|c|}{ 2018- KE* } \\
\hline & Etanol & Metanol & Etanol & Metanol \\
\hline & Ethanol & Methanol & Ethanol & Methanol \\
\hline Gallik asit & ND & $2.9 \pm 0.5^{j}$ & ND & ND \\
\hline 4-hidroksibenzoik asit & $17.3 \pm 2.0^{f}$ & $23.3 \pm 3.0^{f g}$ & $23.3 \pm 2.1^{c}$ & $31.6 \pm 2.4^{d}$ \\
\hline Klorojenik asit & $23.2 \pm 1.6^{\mathrm{d}}$ & $34.9 \pm 3.6^{d}$ & $10.6 \pm 1.3^{\mathrm{e}}$ & $14.3 \pm 1.1^{\mathrm{g}}$ \\
\hline Kafeik asit & $10.8 \pm 0.9^{g}$ & $31.9 \pm 1.1^{e}$ & $8.7 \pm 1.3^{f}$ & $27.4 \pm 1.2^{e}$ \\
\hline Vanilik asit & ND & $4.2 \pm 1.5^{i}$ & ND & ND \\
\hline Siringik asit & $9.5 \pm 1.1^{\mathrm{gh}}$ & $16.3 \pm 2.2^{h}$ & $35.4 \pm 3 . .^{b}$ & $39.4 \pm 2.3^{b}$ \\
\hline Epikateşin & $20.7 \pm 1.5^{\mathrm{ef}}$ & $24.1 \pm 2.6^{f}$ & $21.6 \pm 2.1^{d}$ & $36.3 \pm 2.0^{c}$ \\
\hline p-kumarik asit & $68.8 \pm 3.4^{a}$ & $76.7 \pm 5.0^{a}$ & $20.5 \pm 1.2^{\text {de }}$ & $24.0 \pm 2.6^{f}$ \\
\hline Rutin & ND & ND & ND & $4.0 \pm 0.4^{i}$ \\
\hline Ferulik asit & $21.9 \pm 2.5^{\mathrm{e}}$ & $22.65 \pm 0.8^{g h}$ & $10.0 \pm 0.9^{e f}$ & $9.8 \pm 1.1^{h}$ \\
\hline Benzoik asit & ND & ND & $2.0 \pm 0.5^{\mathrm{g}}$ & $3.5 \pm 0.3^{\mathrm{ij}}$ \\
\hline 2-hidroksisinamik asit & ND & ND & ND & ND \\
\hline Protokatekuik asit & ND & ND & ND & ND \\
\hline Mirsetin & ND & ND & ND & ND \\
\hline Kuersetin & $43.1 \pm 3.8^{c}$ & $52.5 \pm 2.7^{b}$ & $47.6 \pm 3.2^{a}$ & $56.9 \pm 3.7^{a}$ \\
\hline Absisik asit & $57.3 \pm 4.2^{b}$ & $44.7 \pm 3.4^{c}$ & ND & ND \\
\hline
\end{tabular}

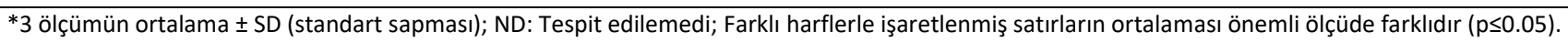




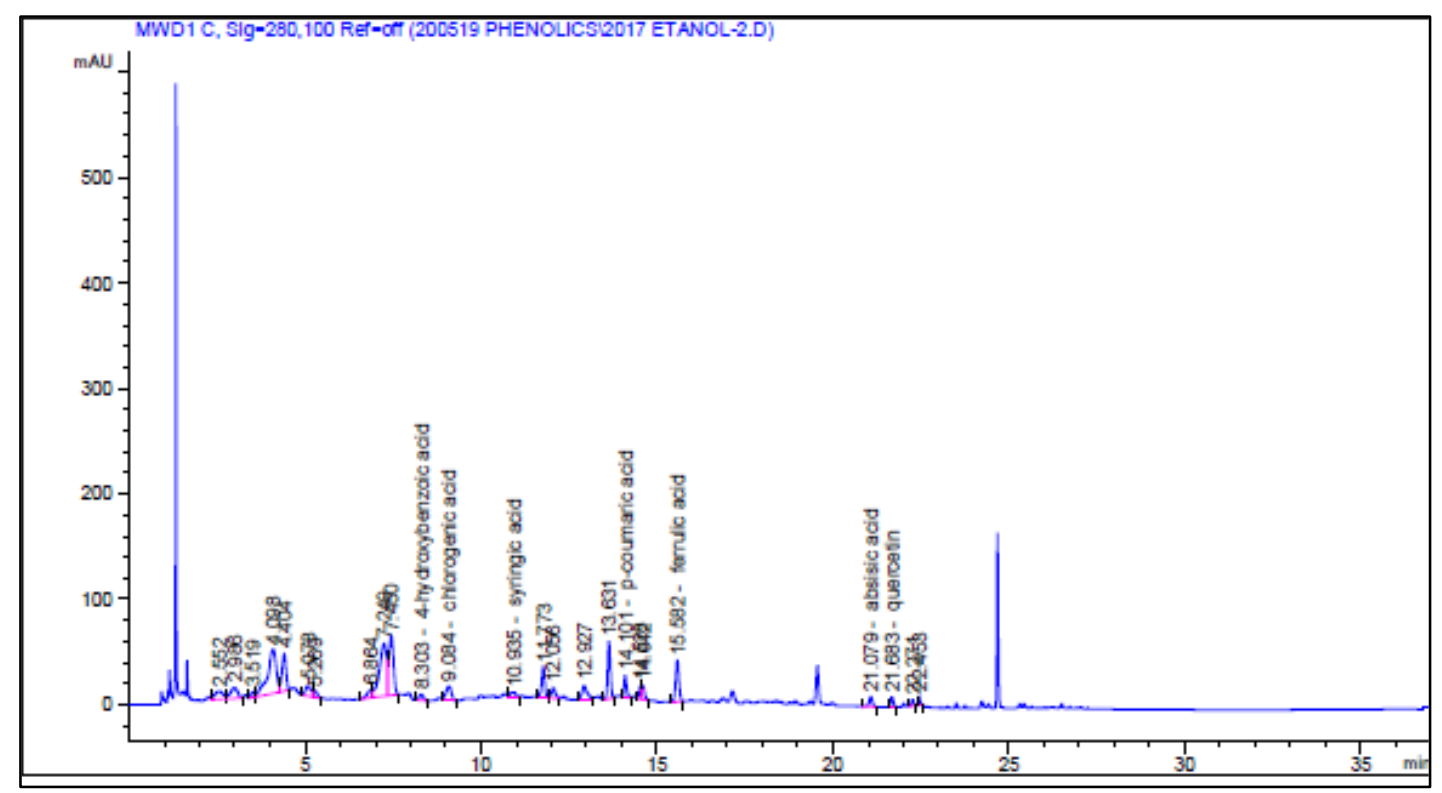

(a)

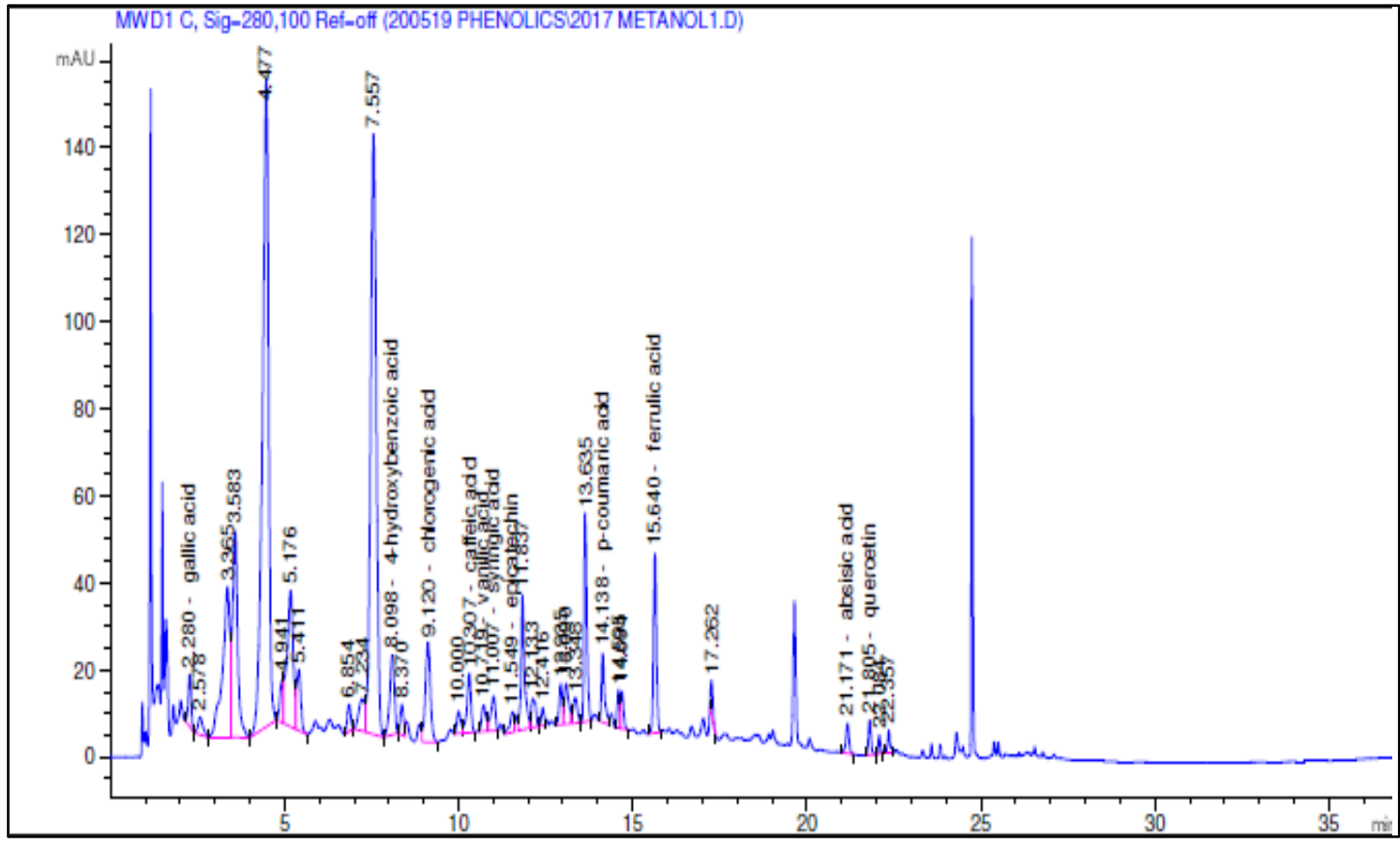

(b)

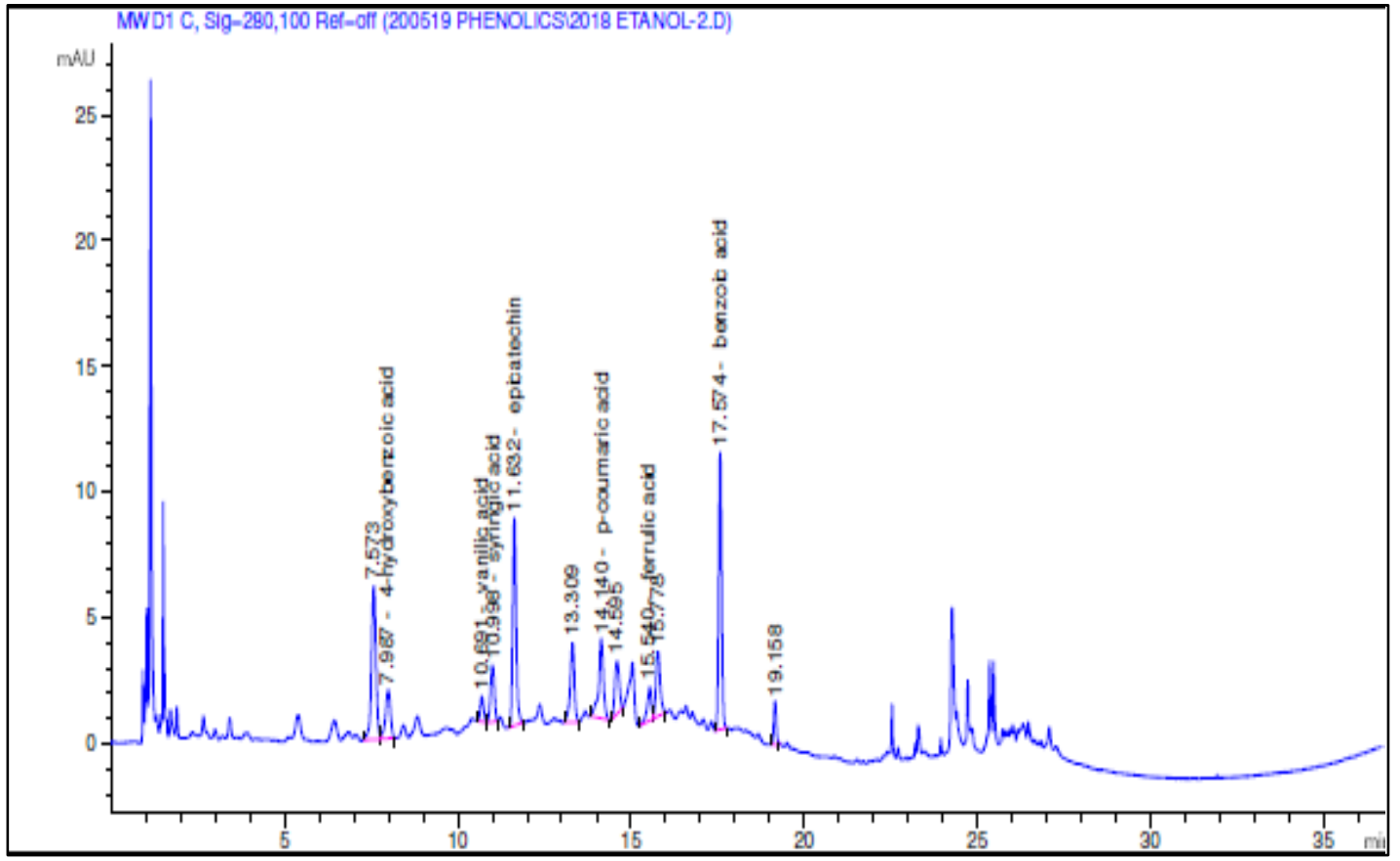

(c) 


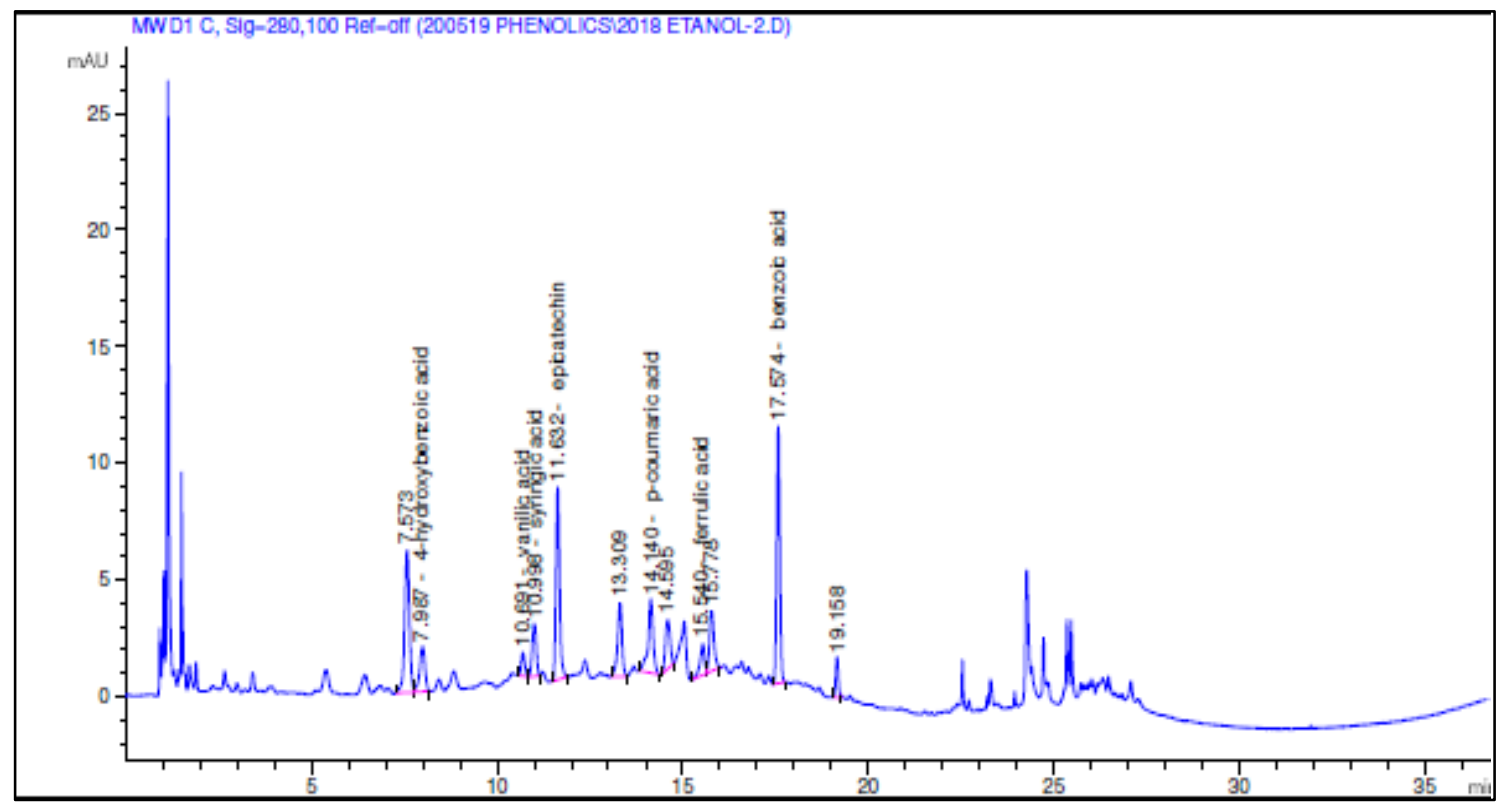

(d)

Şekil 3. Örneklerin etanol ve metanol ekstraktlarının HPLC kromatogramları (a: 2017 Hasat yılında Etanol ile ekstrakte edilen Sibirya kivisine ait fenolik bileşiklere ait kromatogram; b: 2017 Hasat yılında Metanol ile ekstrakte edilen Sibirya kivisine ait fenolik bileşiklere ait kromatogram; c: 2018 Hasat yılında Etanol ile ekstrakte edilen Sibirya kivisine ait fenolik bileşiklere ait kromatogram; d: 2018 Hasat yilında Metanol ile ekstrakte edilen Sibirya kivisine ait fenolik bileşiklere ait kromatogram)

Figure 3. HPLC chromatograms of ethanol and methanol extracts of samples (a: hromatogram of phenolic compounds of Siberian kiwifruit extracted with Ethanol in 2017 harvest year; b: chromatogram of phenolic compounds of Siberian kiwifruit extracted with Methanol in 2017 harvest year; c: chromatogram of phenolic compounds of Siberian kiwifruit extracted with Ethanol in 2018 harvest year, d: chromatogram of phenolic compounds of Siberian kiwifruit extracted with Methanol in 2018 harvest year)

Çalışmamıza benzer olarak, Montanaro ve ark. (2007)'na göre, kivinin başlıca fenolik bileşenleri hidroksisinamik asit, flavonol ve kateşin grubunda yer almaktadır. Kim ve ark. (2009) tarafından kivi meyvesinin etinde saptanan başlıca fenolikler ise kateşin, klorojenik asit, rutin, epikateşin ve kuersetindir.

\section{Antioksidan kapasite analizleri}

Antioksidanlar, aktif radikalleri bağlayarak birçok hastalıktan (kalp, damar, kanser, Alzheimer, katarakt vb.) korunmaya yardımcı olan bileşik grubunun adıdır. Bu grupta; polifenoller, antosiyaninler, karotenoidler, C vitamini, tokoferoller gibi çok sayıda gıda bileşeni yer almaktadır (Langseth, 1995). Çalışmamıza ait, 2017 ve 2018 yıllarında toplanan ve etanol ve metanol gibi iki farklı çözgen ile ekstrakte edilen Sibirya kivisi örneklerine ait ABTS antioksidan kapasite sonuçları Şekil 4'te verilmiştir. Yapılan varyans analizleri sonucunda toplam antioksidan kapasitesi üzerinde hasat yılı ve kullanılan çözgen çeşidinin etkileşimi istatistiksel olarak önemli farklılıklar oluşturmuştur ( $p \leq 0.05)$. Kivi örnekleri arasında en yüksek antioksidan kapasitesi 2018 yılında toplanan ve metanol ile ekstrakte edilen Sibirya kivisinden (118.1 $\mu \mathrm{M}$ TE.g ${ }^{-1}$ TA) alınmıştır. En düşük antioksidan kapasitesi ise 2017 yılında toplanan ve etanol ile ekstrakte edilen kivi örneğinden (87.6 $\mu \mathrm{M}$ TE. $\mathrm{g}^{-1} \mathrm{TA}$ ) elde edilmiştir. Genel olarak 2018 yılında toplanan kivi örneklerinin 2017 yılında toplanan kivi örneklerine göre daha yüksek antioksidan kapasite değerine sahip olduğu görülmektedir. Ayrıca aynı yıl içinde yapılan etanol ve metanol çözgenlerine bağlı olarak yapılan karşılaştırmada metanol ile ekstrakte edilen kivi örneklerinin etanol ile ekstrakte edilen kivi örneklerinden daha yüksek antioksidan kapasite değerinin saptandığı görülmektedir. Çalışmamıza benzer olarak, Park ve ark. (2011) tarafından 4 farklı kivi varyetesinde belirlenen antioksidan kapasite ABTS yöntemine göre 22.9-109 olarak tespit edilmiştir. Araştırmacılara göre, antioksidan kapasite esas olarak C vitamini ve polifenollerden kaynaklanmaktadır. Ekşi ve Özen (2012)' e göre, Antioksidan kapasitesi en yüksek olan çeşit 
Bidan'dır. Bunu Haenam, Daeheung ve Hayward izlemektedir. Wang ve ark. (1996)'a göre, kivi antioksidan kapasitesi ile öne çıkan bir meyve değildir. Fakat, literatür bulgularına göre kivinin antioksidan kapasitesi nar, çilek, portakal ve siyah üzüme göre düşük olmakla birlikte beyaz üzüm, muz, elma, armuta göre oldukça yüksektir.

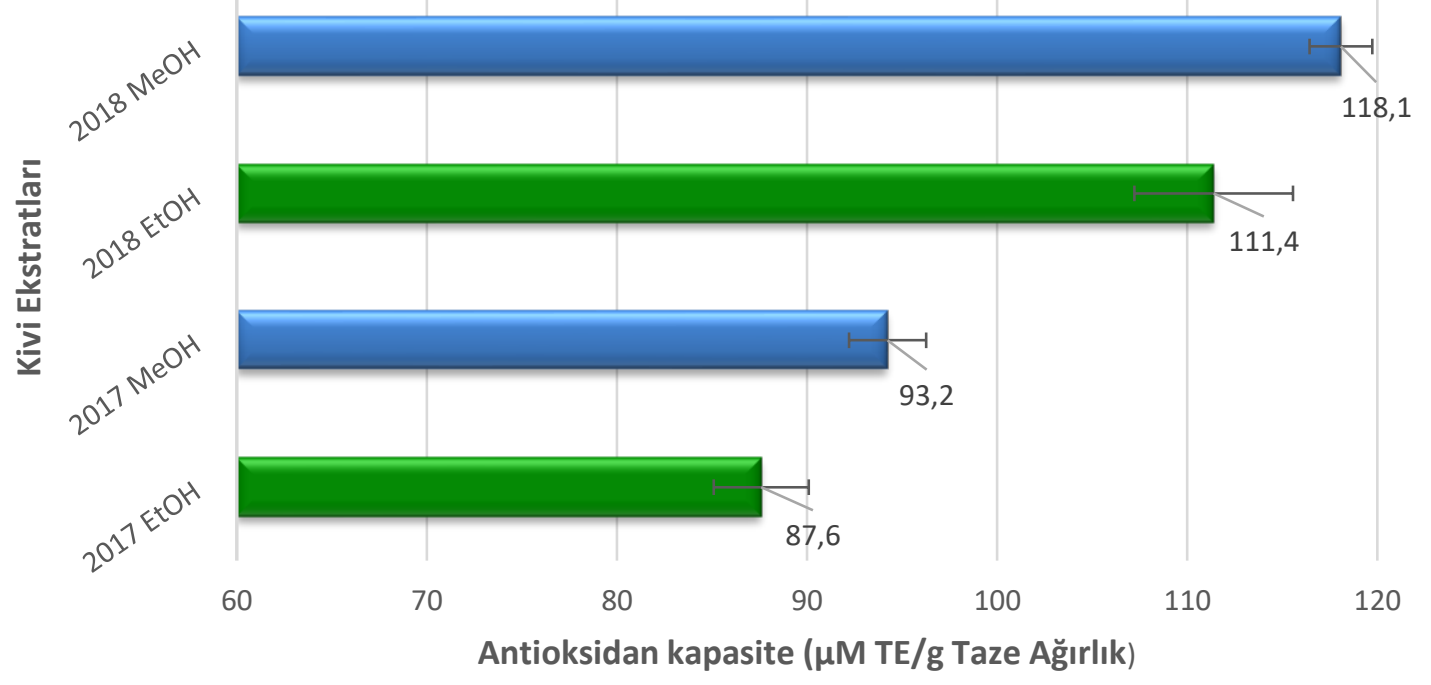

Şekil 4. ABTS yöntemi kullanarak farklı Sibirya kivisi ekstraktlarının antioksidan kapasitesi ( $\mu \mathrm{M}$ TE. $\left.\mathrm{g}^{-1} \mathrm{TA}\right)$ Figure 4. Antioxidant capacity of different Siberian kiwi extracts using ABTS method ( $\mu \mathrm{M} \mathrm{TE} . \mathrm{g}^{-1} \mathrm{FW}$ )

Disk difüzyon yöntemine göre antimikrobiyal etkinin tespitinde, 6-9 mm inhibisyon çapı çok düşük inhibisyon, 9-12 mm inhibisyon çapı düşük inhibisyon, 12-15 mm inhibisyon çapı ortalama inhibisyon ve $15 \mathrm{~mm}$ ve üzeri yüksek inhibisyon olarak değerlendirilmektedir (Engin ve ark., 2019). $\mathrm{Bu}$ değerlendirmeye göre kivi ekstraktlarının hiç biri yüksek inhibisyon göstermemiştir. Çizelge 2'de de görüldüğü üzere, 2018 yılın hasatı olan kivi etanol ekstraklarının Listeria monocytones'e $(13.5 \pm 0.7 \mathrm{~mm})$ karşı en yüksek antimikrobiyal aktiviteyi $40 \mu \mathrm{L}$ emdirilen disk ile gösterdiği tespit edilmiştir. Çizelge 3'de görüldüğü üzere, 2017 yılının hasatı olan kivi metanol ekstraklarının en yüksek antimikrobiyal etkiyi Vibrio parahemolyticus, Enterococcus faecalis, Salmonella Tpyhimurium ve Proteus vulgaris'e $(12.5 \pm 0.7 \mathrm{~mm}) 40 \mu \mathrm{L}$ emdirilen disk ile gösterdiği ile gösterdiği tespit edilmiştir. Tablolarda da görüldüğü gibi tespit edilen antimikrobiyal etki, muamele edilen ekstrakt dozu ile ilişkilidir. Artan dozlarda antimikrobiyal etkinin gözlemlendiği zon çaplarında artış gerçekleşmiştir. S. aureus'un ise, her iki hasat yılı ve farklı ekstrakt kullanımlara karşı en dirençli bakteriyel şus olduğu tespit edilmiştir. En yüksek antimikrobiyal etkinin tespit edildiği mikroorganizmalar Şekil 5'de gösterilmiştir.

Antimikrobiyal özelliklerin belirlenmesi

Çalışmada, etanol ve metanol ile ekstrakte edilen kivi meyvelerinin (2017 ve 2018 yılı hasatları) insan ve gıda patojeni olduğu bilinen bazı mikroorganizmalara karşı antimikrobiyal aktiviteleri belirlenmiştir. Çalışmada, disk difüzyon yönteminin kullanılmış, farklı konsantrasyonlarda (20, 30 ve $40 \mu \mathrm{L}$ ) ekstraktların disklere ilave edilmesi sonrasında sürdürülen inkübasyon ile meydana gelen zon çapların ölçülmesiyle antimikobiyel etki tespit edilmiştir. Ekstraktların antimikrobiyal etkileri sonucu oluşan zon çapları Çizelge 2 ve Çizelge 3'de gösterilmiştir. 
Çizelge 2. Kivi meyvesinin etanol ekstraktlarının antimikrobiyal aktiviteleri $(\mathrm{mm})$

Table 2. Antimicrobial activities of kiwi fruit ethanol extracts $(\mathrm{mm})$

Zon çapları $(\mathrm{mm})$

Inhibition zone diameters $(\mathrm{mm})$

\begin{tabular}{|c|c|c|c|c|c|c|}
\hline \multicolumn{7}{|c|}{ Ekstraktlar (Extracts) } \\
\hline & \multicolumn{3}{|c|}{ 2017-KE* $(\mu \mathrm{L})$} & \multicolumn{3}{|c|}{ 2018-KE* $(\mu \mathrm{L})$} \\
\hline $\begin{array}{l}\text { Mikroorganizmalar } \\
\text { Microorganisms }\end{array}$ & 20 & 30 & 40 & 20 & 30 & 40 \\
\hline Bacillus cereus & $\mathrm{NI}^{\mathrm{a}}$ & $7.0 \pm 0.0^{b}$ & $8.0 \pm 0.0^{b}$ & $\mathrm{NI}^{\mathrm{a}}$ & $7.5 \pm 0.7^{b}$ & $8.5 \pm 0.7^{b}$ \\
\hline Escherichia coli & $7.0 \pm 0.0^{\mathrm{a}}$ & $9.5 \pm 0.7^{b}$ & $10.5 \pm 0.7^{b}$ & $7.0 \pm 0.0^{\mathrm{a}}$ & $8.5 \pm 0.7^{b}$ & $11.0 \pm 0.0^{c}$ \\
\hline Staphylococcus aureus & $\mathrm{NI}^{\mathrm{a}}$ & $\mathrm{NI}^{\mathrm{a}}$ & $\mathrm{NI}^{\mathrm{a}}$ & $\mathrm{NI}^{\mathrm{a}}$ & $\mathrm{NI}^{\mathrm{a}}$ & $\mathrm{NI}^{\mathrm{a}}$ \\
\hline Staphylococcus epidermis & $7.0 \pm 0.0^{\mathrm{a}}$ & $10.5 \pm 0.7^{b}$ & $12.5 \pm 0.7^{c}$ & $7.0 \pm 0.0^{\mathrm{a}}$ & $8.5 \pm 0.7^{b}$ & $10.5 \pm 0.7^{c}$ \\
\hline Vibrio parahemolyticus & $\mathrm{NI}^{\mathrm{a}}$ & $\mathrm{NI}^{\mathrm{a}}$ & $\mathrm{NI}^{\mathrm{a}}$ & $7.0 \pm 0.0^{\mathrm{a}}$ & $8.5 \pm 0.7^{\mathrm{ab}}$ & $9.0 \pm 0.0^{b}$ \\
\hline Yersinia pseudotuberculosis & $7.0 \pm 0.0^{\mathrm{a}}$ & $8.5 \pm 0.7^{\mathrm{ab}}$ & $9.0 \pm 0.7^{b}$ & $7.0 \pm 0.0^{\mathrm{a}}$ & $10.5 \pm 0.7^{b c}$ & $11.5 \pm 0.7^{c}$ \\
\hline Listeria monocytogenes & $7.0 \pm 0.0^{\mathrm{a}}$ & $8.0 \pm 0.0^{\mathrm{a}}$ & $9.5 \pm 0.7^{b}$ & $7.0 \pm 0.0^{\mathrm{a}}$ & $10.5 \pm 0.7^{b}$ & $13.5 \pm 0.7^{c}$ \\
\hline Enterococcus faecalis & $7.0 \pm 0.0^{\mathrm{a}}$ & $8.0 \pm 0.0^{\mathrm{a}}$ & $9.5 \pm 0.7^{b}$ & $7.5 \pm 0.0^{\mathrm{a}}$ & $8.5 \pm 0.7^{\mathrm{ab}}$ & $12.5 \pm 0.7^{b}$ \\
\hline Salmonella Typhimurium & $N I^{a}$ & $N I^{a}$ & $7.0 \pm 0.0^{\mathrm{b}}$ & $\mathrm{NI}^{\mathrm{a}}$ & $7.5 \pm 0.7^{b}$ & $8.5 \pm 0.7^{b c}$ \\
\hline Klebsiella pneumoniae & $\mathrm{NI}^{\mathrm{a}}$ & $7.5 \pm 0.7^{b}$ & $8.5 \pm 0.7^{b c}$ & $\mathrm{NI}^{\mathrm{a}}$ & $7.5 \pm 0.7^{b}$ & $8.5 \pm 0.7^{b c}$ \\
\hline Proteus vulgaris & $7.0 \pm 0.0^{\mathrm{a}}$ & $8.5 \pm 0.7^{b}$ & $10.5 \pm 0.7^{c}$ & $\mathrm{NI}^{\mathrm{a}}$ & $7.5 \pm 0.7^{b}$ & $9.5 \pm 0.7^{c}$ \\
\hline
\end{tabular}

*Ortalama \pm std. sapma; a-c: aynı harflarle gösterilen değerler istatiksel olarak önemli değildir ( $p \geq 0.05)$; 2017-KE: 2017 yılı hasatı Kivi meyvesinin etanol ektraktı; * 2018-KE: 2018 yılı hasatı Kivi meyvesinin etanol ektraktı; NI: Inhibiyon yok.

Çizelge 3. Kivi meyvesinin metanol ekstraktlarının antimikrobiyal aktiviteleri $(\mathrm{mm})$

Table 3. Antimicrobial activities of kiwi fruit methanol extracts $(\mathrm{mm})$

$$
\text { Zon çapları (mm) }
$$

Inhibition zone diameters ( $\mathrm{mm}$ )

\begin{tabular}{|c|c|c|c|c|c|c|}
\hline \multicolumn{7}{|c|}{ Ekstraktlar (Extracts) } \\
\hline & \multicolumn{3}{|c|}{ 2017-KM* $(\mu \mathrm{L})$} & \multicolumn{3}{|c|}{$2018-\mathrm{KM}^{*}(\mu \mathrm{L})$} \\
\hline $\begin{array}{l}\text { Mikroorganizmalar } \\
\text { Microorganisms }\end{array}$ & 20 & 30 & 40 & 20 & 30 & 40 \\
\hline Bacillus cereus & $7.0 \pm 0.0^{\mathrm{a}}$ & $9.0 \pm 1.4^{b}$ & $12.0 \pm 1.4^{\mathrm{c}}$ & $\mathrm{NI}^{\mathrm{a}}$ & $7.5 \pm 0.7^{b}$ & $8.0 \pm 0.0^{b}$ \\
\hline Escherichia coli & $7.0 \pm 0.0^{\mathrm{a}}$ & $9.0 \pm 1.4^{\mathrm{b}}$ & $11.5 \pm 0.7^{c}$ & $7.0 \pm 0.0^{\mathrm{a}}$ & $9.5 \pm 0.7^{b}$ & $11.5 \pm 0.7^{c}$ \\
\hline Staphylococcus aureus & $\mathrm{NI}^{\mathrm{a}}$ & $\mathrm{NI}^{\mathrm{a}}$ & $\mathrm{NI}^{\mathrm{a}}$ & $\mathrm{NI}^{\mathrm{a}}$ & $\mathrm{NI}^{\mathrm{a}}$ & $\mathrm{NI}^{\mathrm{a}}$ \\
\hline Staphylococcus epidermis & $7.0 \pm 0.0^{\mathrm{a}}$ & $8.5 \pm 0.7^{b}$ & $10.5 \pm 0.7^{c}$ & $7.0 \pm 0.0^{a}$ & $10.5 \pm 0.7^{c}$ & $11.5 \pm 0.7^{c}$ \\
\hline Vibrio parahemolyticus & $N I^{a}$ & $9.5 \pm 0.7^{b}$ & $12.5 \pm 0.7^{c}$ & $7.0 \pm 0.0^{a}$ & $8.0 \pm 0.0^{b}$ & $10.5 \pm 0.7^{c}$ \\
\hline Yersinia pseudotuberculosis & $7.0 \pm 0.0^{\mathrm{a}}$ & $8.5 \pm 0.7^{b}$ & $10.5 \pm 0.7^{c}$ & $7.0 \pm 0.0^{\mathrm{a}}$ & $8.5 \pm 0.7^{b}$ & $10.5 \pm 0.7^{c}$ \\
\hline Listeria monocytogenes & $7.5 \pm 0.7^{a}$ & $8.5 \pm 0.7^{a}$ & $12.0 \pm 1.4^{b}$ & $7.0 \pm 0.0^{\mathrm{a}}$ & $7.5 \pm 0.7^{a}$ & $9.5 \pm 0.7^{b}$ \\
\hline Enterococcus faecalis & $7.0 \pm 0.0^{\mathrm{a}}$ & $9.5 \pm 0.7^{b}$ & $12.5 \pm 0.7^{c}$ & $\mathrm{NI}^{\mathrm{a}}$ & $8.5 \pm 0.7^{b}$ & $9.5 \pm 0.7^{c}$ \\
\hline Salmonella Tpyhimurium & $7.0 \pm 0.0^{\mathrm{a}}$ & $9.5 \pm 0.7^{b}$ & $12.5 \pm 0.7^{c}$ & $\mathrm{NI}^{\mathrm{a}}$ & $7.5 \pm 0.7^{b}$ & $9.0 \pm 1.4^{c}$ \\
\hline Klebsiella pneumoniae & $7.0 \pm 0.0^{\mathrm{a}}$ & $8.5 \pm 0.7^{b}$ & $12.0 \pm 1.4^{\mathrm{c}}$ & $\mathrm{NI}^{\mathrm{a}}$ & $7.0 \pm 0.0^{b}$ & $8.5 \pm 0.7^{c}$ \\
\hline Proteus vulgaris & $7.5 \pm 0.7^{a}$ & $9.0 \pm 0.0^{b}$ & $12.5 \pm 0.7^{c}$ & $\mathrm{NI}^{\mathrm{a}}$ & $N I^{a}$ & $7.0 \pm 0.0^{b}$ \\
\hline
\end{tabular}

* Ortalama \pm std. sapma; ; a-c: aynı harflarle gösterilen değerler istatiksel olarak önemli değildir(p $\geq 0.05)$; 2017-KM: 2017 yılı hasatı Kivi meyvesinin etanol ektraktı; * 2018-KM: 2018 yılı hasatı Kivi meyvesinin etanol ektraktı; NI: İnhibiyon yok.

Çizelge 2 ve 3'te de görüldüğü üzere, kivi meyvesinin metanol ekstraktları, etanol ekstraktlarına kıyasla daha yüksek bir antimikrobiyal etki göstermiştir. Çalışma sonuçlarımıza benzer olarak Mishia ve ark. (2010) kivi metanol ekstraktlarının daha yüksek antimikrobiyal aktivite gösterdiklerini tespit etmişlerdir. Nessma Ahmed (2015) kivi ekstraklarının en yüksek antimikrobiyal etkiyi $S$. aureus, K. pneumonia ve C. albicans'a karşı gösterdiğini bildirmişlerdir. Farklı ekstraktların farklı antimikrobiyal etkilere sahip olması, farklı 
içerikleri ve aktif bileşikleri ile patojen bakterilerin gelişmesini önleyici mekanizmalara sahip olmaları ile açıklanabilir (He ve ark., 2002). Bu nedenle farklı çözgenler kullanılarak daha fazla çalışma yapılmalıdır. Mann ve ark. (2015) tarafından yapılan çalışmada ise kivi ekstraktlarının gösterdiği antimikrobiyal etki içerdiği flavonoidlerle ilişkilendirilmiştir. Çalışmamız bulgularının aksine araştırmacılar, ekstrakt içeriğindeki flavonoidlerin, S. aureus ile ilişkili enfeksiyonun tedavisinde vankomisinden gelen benzer antimikrobiyal aktivitesi nedeniyle $S$. aureus'a potansiyel bir alternatif ilaç olabileceği öne sürmüşlerdir. Çalışmamızın antimikrobiyel analiz sonuçları, yaygın olarak tüketilen kivi meyvelerinin umut verici antimikrobiyal aktiviteler içerebileceğini ortaya koymuştur. Bununla birlikte, bu çalışma in vitro veriler sunmaktadır. Bu in vitro bulguları doğrulayabilen yeni antimikrobiyal bileşiklerin izolasyonu ve in vivo çalışmaların yapılması önerilmektedir.

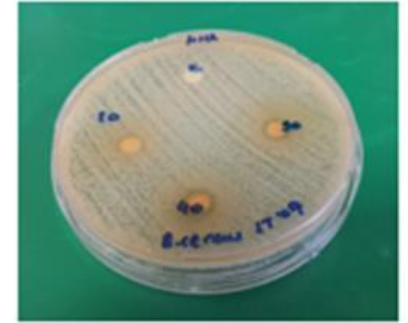

Bacillus cereus

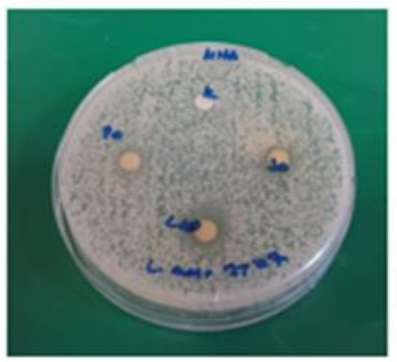

Listeria monocytogenes

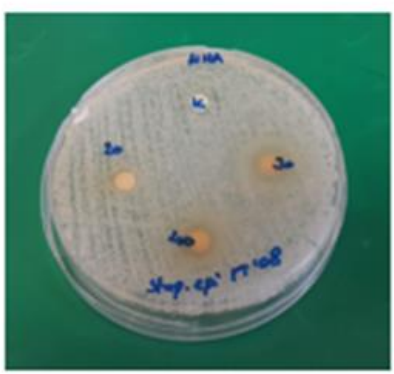

Staphylococcus epidermis

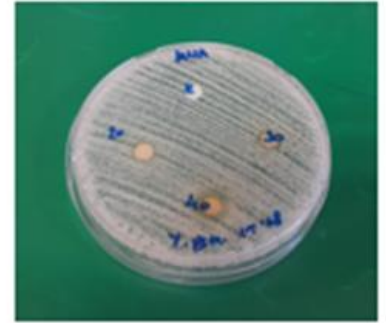

Yersinia pseudotuberculosis

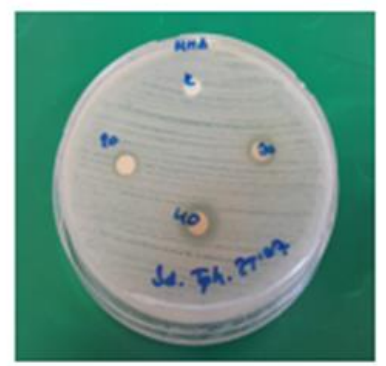

Salmonella Tpyhimurium

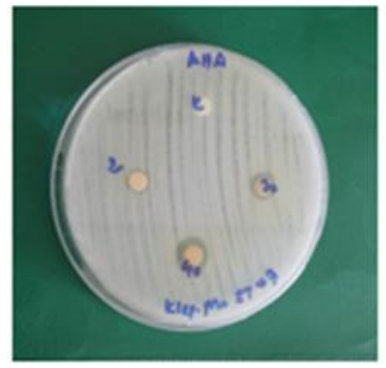

Klebsiella pneumoniae

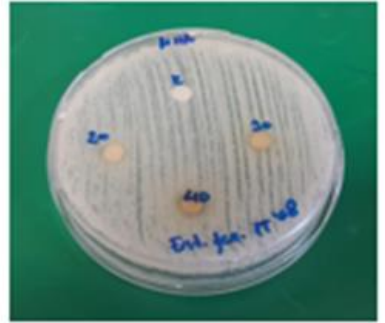

Enterococcus faecalis

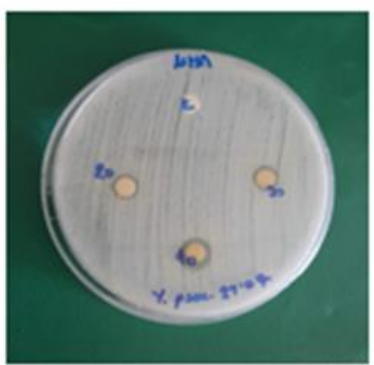

Yersinia pseudotuberculosis

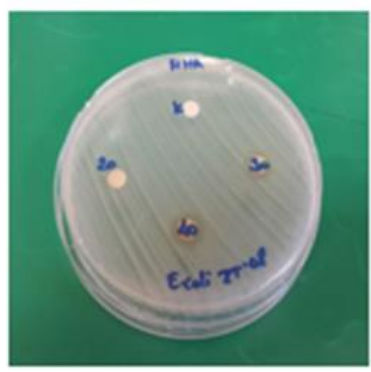

Escherichia coli

Şekil 5. Kivi meyvesinin etanol ve metanol ektraktlarının bazı patojen bakterilere karşı gösterdiği antimikrobiyal etkiler Figure 5. The antimicrobial effects of kiwi fruit's ethanol and methanol extracts against some pathogenic bacteria

\section{Sonuçlar}

Sonuç olarak, bu çalışmada Trabzon bölgesinde yetişen Sibirya kivisi ( $A$. arguta) meyvelerine ait ekstraktların biyoaktif özellikleri ilk defa rapor edilmiştir. Bu bağlamda, çalışılan ekstraktların konsantrasyon miktarları artışı ile önemli gıda kaynaklı patojen mikroorganizmalara karşı antimikrobiyal etkinliğin arttığı tespit edilmiştir.
2017 hasat yılında etanol ile ekstrakte edilen kivi örneklerindeki en yüksek fenolik bileşikler pkumarik asit ve kuersetin olurken tespit edilebilen en düşük fenolik bileşikler şiringik asit ve kafeik asit olmuştur. Aynı şekilde 2017 yılında metanol ile ekstrakte edilen kivi örnekleri için en yüksek fenolik bileşikler p-kumarik asit ve kuersetin olurken, tespit edilen en düşük fenolik bileşikler vanilik ve gallik asit olmuştur. Absisik asit 2017 
yılında hasat edilen ve her iki çözgen ekstraktında tespit edilirken 2018 yılı ekstraktlarında bulunamamıştır. Ekstraktların antioksidan ve antimikrobiyal etkilerinin içerdikleri majör ve minör bileşenlerin birlikte oluşturduğu etkiden kaynaklandığı düşünülmektedir. Analiz sonuçlarına göre taşıdığı biyoaktif özelliklerle Sibirya kivisinin, sağlıklı bir beslenmenin fonksiyonel bir ögesi olarak öneminin ve tüketiminin artış göstermesi beklenmektedir.

\section{Ekler}

$\mathrm{Bu}$ çalışma Giresun Üniversitesi Bilimsel Araştırma Projeleri Koordinasyon Birimi'nce maddi olarak desteklenmiştir (Proje No: FEN-BAPA-230218-07).

\section{Çıkar Çatışması Beyanı: Makale yazarları} aralarında herhangi bir çıkar çatışması olmadığını beyan ederler.

Yazar Katkısı: Mustafa R. OTAĞ çalışmayı planlayarak denemeleri kurmuş, Selin KALKAN, Mustafa R. OTAĞ ve M. Soner ENGIN çalışmayı yürütmüş, Mustafa R. OTAĞ ve M. Soner ENGIN verileri analiz etmiş, Selin KALKAN, Mustafa $R$. OTAĞ ve M. Soner ENGIN makaleyi yazmıştır.

\section{Kaynaklar}

Akmeşe, O., Acet, T., \& Özcan, K.(2020). Elazığ i̇linde Yetişen Morus nigra L.'nin Antioksidan ve Antimikrobiyal Aktivitelerinin ve Antibiyotiklerle Sinerjistik Etkisinin Belirlenmesi. Gümüşhane Üniversitesi Fen Bilimleri Enstitüsü Dergisi, 10(4), 983-995.

Alonso Borbalán, Á.M., Zorro, L., Guillén, D.A. \& García Barroso, C. (2003). Study of the polyphenol content of red and white grape varieties by liquid chromatography-mass spectrometry and its relationship to antioxidant power. Journal of Chromatography A, 1012 (1), 31-38.

Bravo, L. (1998). Polyphenols: Chemistry, dietary sources, metabolism, and nutritional significance. Nutrition Reviews, 56, 317-333.

Bridle, P. (1996). A simple technique for the detection of red wine adulteration with elderberry pigments. Food Chemistry, 55, 111-113.

Briviba, K., \& Sies,H. (1994). Natural Antioxidants in Human Health and Disease. London: Academic Press.

Chang, L.C., \& Kinghorn, A.D. (2001). Flavonoids as cancer chemopreventive agents. In C. Tringali (Ed.),
Bioactive Compounds from Natural Sources. London/New York: Taylor \& Francis.

Chesoniene, L., Daubaras, R. \& Viskelis, P. (2004). Biochemical composition of Berries of some Kolomikta Kiwi (Actinidia kolomikta) cultivars and detection of Harvest maturity. Acta Horticulturae, 663, 305-308.

Cordell, G.A., Lemos, T.L.G., Monte, F.J.Q. \& de Mattos, M.C. (2007). Vegetables as chemical reagents. Journal of Natural Products, 70(3), 478-492.

Çelik, A., Ercisli, S. \& Turgut, N. (2007). Some physical, pomological and nutritional properties of kiwifruit cV Hayward. International Journal of Food Sciences and Nutrition, 58, 411-418.

Davidson, P.M., \& Naidu, A.S. (2000). Natural food antimicrobial systems. Boca Raton, Florida: CRC Press.

Dimitrios, B., (2006). Sources of natural phenolic antioxidants. Trends in Food Science \& Technology, 17(9), 505-512.

Du, G., Li, M., Ma, F., \& Liang, D. (2009). Antioxidant capacity and the relationship with polyphenol and vitamin C in Actinidia fruits. Food Chemistry, 113(2), 557-562.

Ekşi, A. \& Özen, I.T. (2012). Kivi meyvesinin kimyasal bileşenleri ve fonksiyonel özellikleri. Ordu Üniversitesi Bilim ve Teknoloji Dergisi, 2(2), 54-67.

Elliot, J.G. (1999). Application of antioxidant vitamins in foods and beverages. Food Technology, 53,46-48.

Engin, M. S., Kalkan, S., \& Otağ, M.R. (2019). Gojiberry (Lycium barbarum L.) Meyvesinin Farklı Çözgenlerden Elde Edilen Ekstraktlarının Toplam Fenolik İçerikleri ìle Antioksidan ve Antimikrobiyal Aktivitelerinin Karşılaştırılması. Journal of Anatolian Environmental and Animal Sciences, 4(3), 359-365.

Erkoç, Ş., Erkoç, F., \& Keskin, N. (2003). Theoretical investigation of quercetin and its radical isomers. Journal of Molecular Structure:THEOCHEM, 631(1-3), 141-146.

Fabre, N., Rustan, I., de Hoffmann, E., \& Quetin-Leclercq, J. (2001). Determination of flavone, flavonol, and flavanone aglycones by negative ion liquid chromatography electrospray ion trap mass spectrometry. Journal of the American Society for Mass Spectrometry, 12(6), 707-715.

Ferguson, A.R. (1984). Kiwifruit: A botanical review. Horticultural Reviews, 6,1-64.

Ferguson, A.R. (1990). The genus Actinidia. In I.J. Warrington and G.C. Weston (Ed.) Kiwifruit Science and Management (pp. 15-35). Auckland: Richards Publisher.

Frankel, E.N., (1999). Food antioxidants and phytochemicals: present and paste. Fett/ Lipid, 101, 450-455.

Fridovich, I., (1999). Fundamental aspects of reactive oxygen species, or what's the matter with oxygen? Annals of the New York Academy of Sciences, 893, 13-18.

Gorinstein, S., Poovarodom, S., Kruszewska, H., Leontowicz, M., Namieśnik, J., \& Vearasilp, S., (2010). Antioxidant properties and bioactive constituents of some rare exotic Thai fruits and comparison with conventional fruits: In vitro and in vivo studies. Food Research 
International, 44, 2222-2232.

Gorinstein, S., Leontowicz, H., Leontowicz, M., Jesion, I., Namiesnik, J., Drzewiecki, J., \& Trakhtenberg, S. (2011). Influence of two cultivars of persimmon on atherosclerosis indices in rats fed cholesterolcontaining diets: Investigation in vitro and in vivo. Nutrition, 27, 838-846.

Gülçin, I., Oktay, M., Kirecci E., \& Küfrevioğlu Ö.I., (2004). Screening of antioxidant and antimicrobial activities of anise (Pimpinella anisum L.) seed extracts. Food Chemistry, 83, 371-382.

Gümüşay, Ö. A., \& Yalçın, M. Y. (2019). Effects of FreezeDrying Process on Antioxidant and Some Physical Properties of Cherry Laurel and Kiwi Fruits. Akademik Gıda, 17(1), 9-15.

He, B., Chen, X. X., \& Chen, Y. (2002). Protective Effects of Tea Polyphenol on Cerebral Ischemia Reperfusion Injury in Rats and Its Scavenging Oxy-radical and Anticerebral Lipid Peroxidation Efects. Journal of Chinese Pharmaceutical Sciences, 11(4), 167-171.

Hou, D.X. (2003). Potential mechanisms of cancer chemoprevention by anthocyanins. Current Molecular Medicine, 3,149-159.

Huang, D., Ou, B., \& Prior, R. L. (2005). The chemistry behind antioxidant capacity assays. Journal of Agricultural and Food Chemistry, 53, 1841-1856.

Kabaluk, A.K., Kempler, C., \& Toivonen, P.M.A. (1997). Actinidia arguta- characteristics relevant to commercial production. Fruit varieties journal, 51, 117-122.

Kalkan, S. (2016). Probiyotik Laktik Asit Bakterilerinin Staphylococcus aureus'a Karşı Antimikrobiyal Etkilerinin Farklı Matematiksel Modeller ile Analizi. Sinop Üniversitesi Fen Bilimleri Dergisi, 1(2), 155-164.

Kalt, W. (2005). Effects of production and processing factors on major fruit and vegetable antioxidants. Journal of Food Science, 70, R11-R19.

Kamei, H., Kojima, T., Hasegawa, M., Koide, T., Umeda, T., \& Yukawa, T., (1995). Suppression of tumor cells by anthocyanins in vitro. Cancer Investigation, 13, 590594

Karaivanova, M., Drenska, D., \& Ovcharov, R.A. (1990). Modification of the toxic effects of platinum complexes with anthocyanins. Eksperimentalna meditsina i morfologiia, 29, 19-24.

Kim, J.G., Beppua, K., \& Kataokaa, I. (2009). Varietal differences in phenolic content and astringency in skin and flesh of hardy kiwifruit resources in Japan. Scientia Horticulturae, 120(4), 551-554.

Kong, J.M., Chia, L.S., Goh, N.K, Chia, T.F., \& Brouillard, R. (2003). Analysis and biological activities of anthocyanins. Phytochemistry, 64, 923-933.

Krupa, T., Latocha, P.\& Liwińska A. (2011). Changes of physiological quality, phenolics and vitamin $C$ content in hardy kiwifruit (Actinidia aruguta and its hybrid) during storage. Scientia Horticulturae, 130, 410-417

Langseth L., (1995). Oxidants, antioxidants and disease prevention. Brussels: ILSI Europe.

Macheix, J.J., Fleuriet, A., \& Billot, J. (1990). Fruit Phenolics. Boca Raton, Florida: CRC Press, $390 \mathrm{p}$.

Mann, S., Sharma, A., Biswas, S., \& Gupta, R. K. (2015). Identification and molecular docking analysis of active ingredients with medicinal properties from edible Baccaurea sapida. Bioinformation, 11(9), 437443.

Matich, A.J., Young, H., Allen, J.M., Wang, M.Y., Fielder, S., McNeilage, M.A., \& MacRae, E.A. (2003). Actinidia arguta: volatile compounds in fruit and flowers. Phytochemistry, 63, 285-301.

Mishra, N., Dubey, A. Singh, N. \& Gupta, P. (2010). Antimicrobial, antioxidant and chemopreventive potential of vitamin $\mathrm{C}$ rich fruits. International Journal of Applied Biology and Pharmaceutical Technology, 1(3), 915-920.

Montanaro, G., Treutter, D., \& Xiloyannis, C. (2007). Phenolic compounds in young developing kiwifruit in relation to light exposure: Implications for fruit calcium accumulation. Journal of Plant Interactions, 2(1), 63-69.

Mulero, J., Pardo, F., \& Zafrilla, P. (2010). Antioxidant activity and phenolic composition of organic and conventional grapes and wines. Journal of Food Composition and Analysis, 23(6), 569-574.

Nessma, A. (2015). Antioxidant, Antitumor, Antimicrobial Studies and Quantitative Phytochemical Estimation of Ethanolic Extracts of Selected Fruit Peels. International Journal of Current Microbiology and Applied Sciences, 4(5), 298-309.

Ohashi, H., (1989). Actinidiaceae. In Y., Satake, H., Hara, S., Watari, T. Tominari, (Ed.), Wild Flowers of Japan: Woody plants (pp.135-137) .Tokyo: Heibonsha Ltd.,

Park, Y.S., Jung, S. T., Kang, S.-G., Drzewiecki, J., Namiesnik, J., Haruenkit, R., \& Gorinstein, S. (2006). In vitro studies of polyphenols, antioxidants and other dietary indices in kiwifruit (Actinidia deliciosa). International Journal of Food Sciences and Nutrition, 57, 107-122.

Park, Y.S., Leontowicz, H., Leontowicz, M., Namiesnik, J., Suhaj, M., Cvikrov, M., \& Gorinstein, S. (2011). Comparison of the contents of bioactive compounds and the level of antioxidant activity in different kiwifruit cultivars. Journal of Food Composition and Analysis, 24, 963-970.

Pietta, P.G. (2000). Flavonoids as antioxidants. Journal of Natural Products, 63, 1035-1042.

Prasain, J.K., Wang, C.C., \& Barnes, S., (2004). Mass spectrometric methods for the determination of flavonoids in biological samples. Free Radical Biology and Medicine, 37 (9), 1324-1350.

Re, R., Pellegrini, N., Proteggente, A., Pannala, A., Yang, M., \& Rice-Evans, C.A., (1999). Antioxidant activity applying animproved ABTS radical cation decolorization assay. Free Radical Biology and Medicine, 26 (9-10), 1231-1237.

Rice-Evans, C.A., Miller, N.J., \& Paganga, G., (1996). Structure-antioxidant activity relationships of flavonoids and phenolic acids. Free Radical Biology and Medicine, 20 (7), 933-956.

Roginsky, A.B., Ujiki, M.B., Ding, X.Z., \& Adrian, T.E. (2005). On the potential use of flavonoids in the treatment and prevention of pancreatic cancer. In Vivo, 19,6167.

Rush, E. C., Patel, M., Plank, L. D., Ferguson, L. R. (2002). Kiwifruit promotes laxation in the elderly. Asia Pacific Journal of Clinical Nutrition, 11(2), 164-168. 
Samancı, H., (1990). Kivi (Actinidia) Yetistiriciliği, Yalova :TAV Yayınları.

Schuster, B., \& Herrmann, K. (1985). Hydroxybenzoic and hydroxycinnamic acid derivatives in soft fruits. Phytochemistry, 24, 2761-2764.

Shahidi, F., \& Naczk, M. (1995). Antioxidant Properties of Food Phenolics. In F. Shahidi \& M. Naczk (Ed.), Food Phenolics: Sources, Chemistry, Effects and Applications (pp. 235-277). PA: Technomic Publishing Co.

Slinkard, K., \& Singleton, V. L. (1997). Total phenol analysis: automation and comparison with manual methods. American Journal of Enology and Viticulture, 28, 4955.

Spacil, Z., Novakova, L., \& Solich, P. (2008). Analysis of phenolic compounds by high performance liquid chromatography and ultra performance liquid chromatography. Talanta, 76(1), 189-199.

Stanley, R. Wegrzyn, T. \& Saleh, Z. (2006). Kiwifruit processed product. Acta Horticulturae, 753, 795-800.

Strik, B., \& Hummer, K., (2006). Ananasnaya' hardy kiwifruit. Journal of the American Pomological Society, 60, 106-112.

Suschetet, M., Siess, M.H., Le Bon, A.M., \& Canivenc-Lavier, M.C. (1998). Anticarcinogenic properties of some Favonoids. In J. Vercauteren, C. Cheze \& J. Triau
Polyphenols 96 (pp. 165-204). Paris: INRA.

Türkkan M., Erper I., Kılıçoğlu M.Ç., Yazıcıoğlu E. \& Özcan, M. (2018). Characterization and pathogenicity of Rhizoctoniaspp. isolated from kiwifruit in the Middle and Eastern Black Sea region of Turkey. Journal of Phytopathology 166(11-12), 761-774.

Velioğlu, Y.S., Ekici, L., \& Poyrazoğlu, E.S., (2006). Phenolic composition of European Cranberry bush (ViburnumopulusL.)berries and astringency removal of its commercial juice. International Journal of Food Science and Technology , 41, 1011-1015.

Williams, M.H., Boyd, L.M., McNeilage, M.A., MacRae, E.A., Ferguson, A.R., Beatson, R.A., \& Martin, P.J., (2003). Development and commercialization of 'Baby Kiwi' (Actinidia arguta Planch). Acta Horticulture, 610, 8186.

Wollgast, J., \& Anklam, E. (2000). Review on polyphenols in The obroma cacao: Changes in composition during the manufacture of chocolate and methodology for identification and quantification. Food Research International, 33, 423-447.

Yonat, H., \& Kolören, O. (2017). Determination of Weed Species in Kiwifruit Orchards of Ordu ProvinceTurkey. Harran Tarım ve Gıda Bilimleri Dergisi, 21, 155-163. 